\title{
Feminism and hospitality
}

\section{Religious and critical perspectives in dialogue with a secular age}

DOI: https://doi.org/10.30664/ar.98374

$\mathrm{H}$ ow to think hospitality in a secular age? The study circle on hospitality and solidarity, 'Feminist Philosophy in Thought, History and Action', which is part of the Nordic Summer University (NSU) organised a winter symposium in March 2020 in Turku/Åbo, Finland. The symposium was arranged in collaboration with the Donner Institute and cofunded by both the Polin Institute and Åbo Akademi University. The goal was to bring together students and scholars from diverse educational and geographical backgrounds to explore the question of hospitality in a contemporary setting. Taking into consideration religious and philosophical perspectives, while also being grounded in the complex reality of today, participants exchanged thoughts and ideas over four days. What resulted was, in the words of one of the participants, 'hours of learning, mutual study and exploration' (Izraeli, this issue). Essential to the evolution of these discussions was not only the space provided for them by the partnering institutions, but also the fact that we were able to eat and walk and breathe within and through the framework of hospitality (Barroso, this issue). Between the joint dinners around Turku/Åbo and the accommodation facilities provided by the Bridgettine nuns of the convent, a new sphere of exploring how hospitality can be sensed and experienced was added to the layers provided by the thoughts and writings we shared.

This NSU study circle is in itself a practice of hospitality and solidarity. As coordinators we attempt to create a space in which content and form align. Thought does not happen in a void, but in the space between people. Allowing for the vulnerability that is part of that encounter, it is possible to open up a question for everyone to partake of and to give to. Giving, in the sense described by Marcel Mauss ('Essai sur le don: forme et raison de l'échange dans les sociétés archaïques', 1925), as that practice that gives away a part of one's self in order to receive back something that becomes part of the new self. What one takes from the symposia organised by the study circle is a sense of community - of thinking together and furthering one's own thought in solidarity with the thoughts of others. Even though it remains impossible to think for another, there is a new sense of belonging. Not because one agrees with what is said, but because things can be said, because things don't need to be said.

It is this act of hospitality that is the focus of this special issue. The approaches that the authors take are diverse, each adding their 

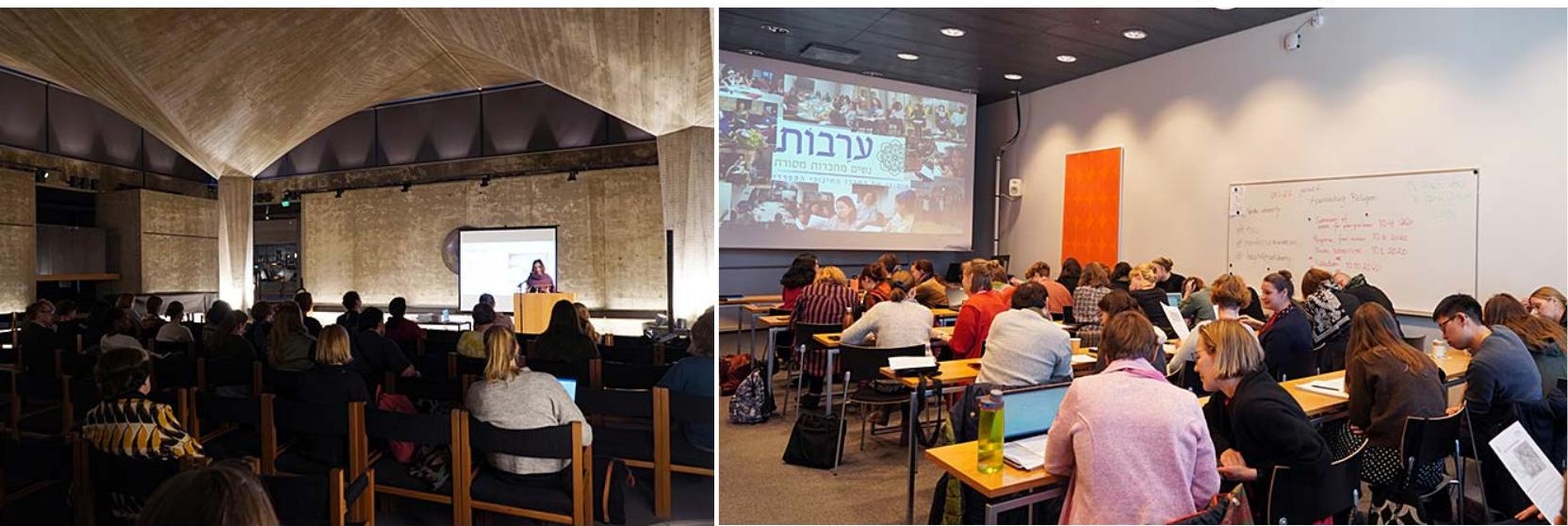

Left: Professor Terhi Utriainen giving her keynote talk in the Sibelius Museum. Right: Angy Cohen and Sagy Watemberg Izraeli lead the whole symposium in a reading of the story of Esther in the Torah as they would do in Arevot, their House of Study.

own layer to the complexity of hospitality. Perhaps this collection of perspectives will live up to the sisterhood of letters that Rita Niineste calls for - as a solidarity modelled after a sisterhood of letters that existed in seventeenth-century Europe. This sisterhood is not the strictly unified community of feminists that Simone de Beauvoir called for. However, it is arguable whether shared intellectual endeavours that are grounded in and coloured by everyone's own history and experience, do create a community. Niineste outlines what would be needed for such a community: a commitment to philosophical openness and fundamental curiosity.

It is this openness and curiosity for the world and how it is lived that can be found in every article in this issue. Even though the approaches that are used are diverse, and every author brings along their own body of thought and experiences - yet each author in their own way asks what it means to be hospitable. Kaia Rønsdal answers this question through interviewing people in the borderland of North Norway where migrants and local residents have engaged in acts of hospitality. By exploring this space of the encounter, she is outlining an embodied hospitality - a concept closely tied to the idea of borders, heterotopias and non-spaces, and the surprise of the new that comes to us through the rupture that is contained in the potential of the encounter.

Heidi Jokinen shows that hospitality can also be understood anew by examining the practice of restorative justice in cases of domestic violence. Within restorative justice hospitality can be practised as a kind of hospitality towards the enemy. It is at this extreme situation within restorative justice, which focusses on the potential of the encounter between victim and offender, that we can find the profound attitude that is hospitality: a moral practice dealing with the other, the stranger. There is an inherent risk within the practice of hospitality, as outlined by feminist critiques of the practice, which however, according to Jokinen, is not a reason to forego the possibility of hospitality that is entailed in the practice of restorative justice. It is the risk-taking involved in the act of hospitality that provides agency and empowerment - even for a victim of domestic violence - irrespective of what the response is, or whether there even is a response to the hospitality; or so Jokinen argues. 
What is risked is one's identity. Opening up to otherness can mean the end of a (religious) tradition. In her article on the vernacular practices of intermarried Finnish Jewish women, Mercédesz Czimbalmos finds that Judaism isn't abandoned, but through creating and (re-)inventing traditions they find meaningful ways of 'doing religion' and 'being Jewish'. This reinvention and natal rebeginning is questioned by Lucy Benjamin, who brings up Hannah Arendt's notion of natality in connection to Walter Benjamin's weak messianisms, to argue in favour of the unpredictability that this kind of hospitality brings about. In her reading, Benjamin opens the possibility for solidarity, allowing for an alternative to the capitalist and colonial consequentialism that are normalised in the Anthropocene.

How to speak about the act of opening up to someone, without already limiting the other's possibilities? How to receive the other, without bunching everyone into the same category? Angy Cohen explores the possibility of a women's perspective on hospitality through a resistance to the patriarchal reclusion of the woman-mother who is left unnamed, as well as the postmodern deconstruction of the category of 'woman'. And in doing so, she is interrupting the established narratives. What Cohen searches for is a story of women which she says is 'looking for the creation of a language that will speak it'. She raises the possibility of a border zone of hospitality in which traditions and different worlds and tensions can be allowed. Reclaiming the space of the home and providing it with epistemic and moral authority. To allow for the ambiguity of the other, as a response to the stranger that is hospitality.

To do so, Jakob Signäs focusses on yet another aspect of the encounter of hospitality. He argues that we will need to rethink what constitutes one's neighbour, as to be a

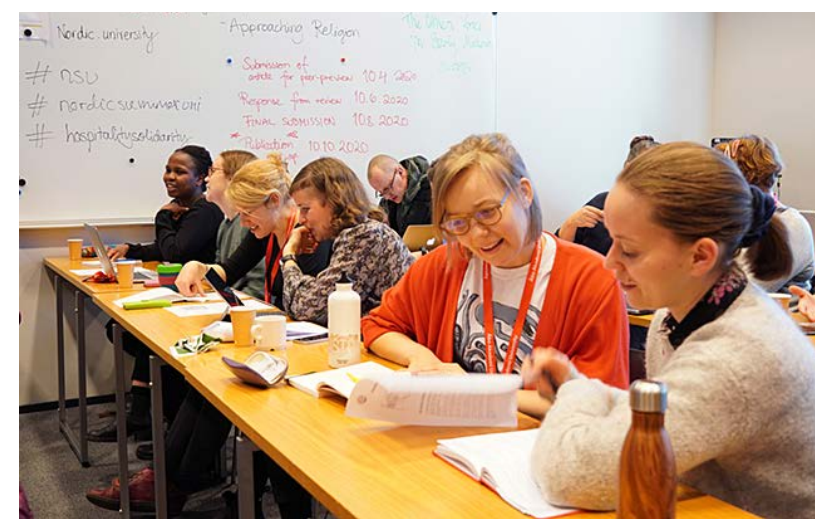

Intense discussions on how to understand the hospitality offered by Esther and the Persian king.

responsible human we will need to do without anthropocentricism, so that we will be able to acknowledge the ontological reality of interdependency and interrelatedness as the ground for being. Signäs develops the argument for how this calls for a particular responsibility on the part of humanity, and he formulates a view of how humanity should act in the world and towards other beings.

Anne Sauka shows that in order to embrace hospitality, we will also need to let go of the recurrent binary mode in Western thought that makes us choose between an object-oriented understanding of the body with the resulting ethical paradigm of 'reactive nihilism' on the one hand, and the processuality of a lived body on the other. Sauka claims that what is at stake is the possibility of meaning-making. By searching for a perspective on the lived body, she aims to overstep the usual conflictual relationship 'between scientific skepticism and atheism, and religious faith-based convictions and praxes' (Sauka, this issue).

An example of this is presented by Laura Hellsten, who asks what an ethical response looks like when acknowledging the entangled networks of relationships that make up human life. What kind of agency 

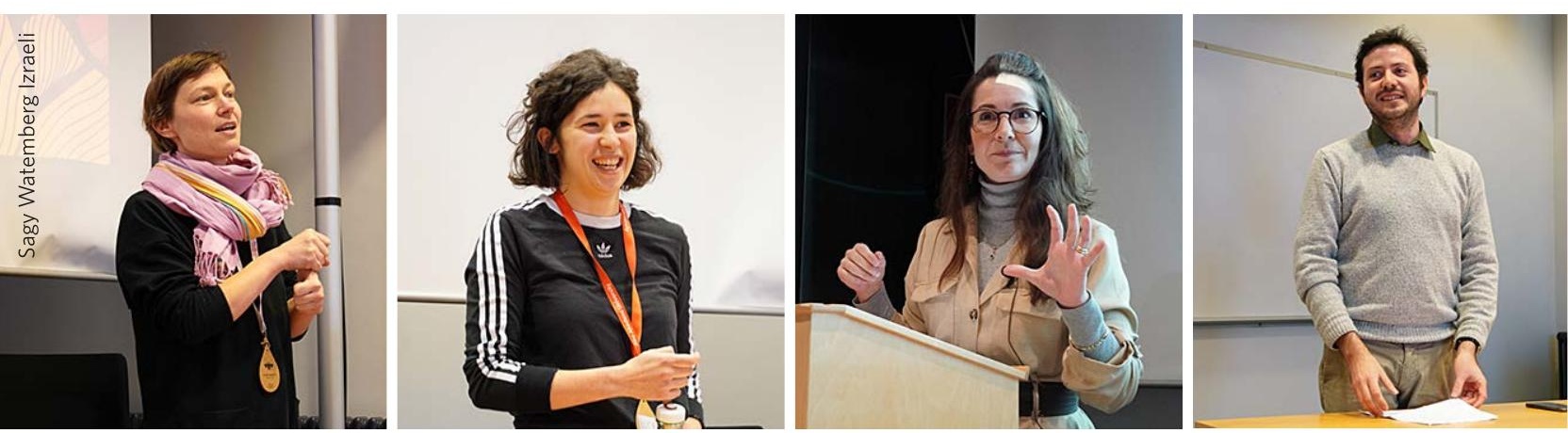

From the left: Heidi Jokinen presenting her paper on restorative justice. Lucy Benjamin discusses natality in connection with Walter Benjamin. Angy Cohen giving her keynote talk on the female labour of care in hospitality in the Jewish tradition. Israel Barroso speaking about the New Testament characters Mary and Martha and how they can be understood in a new way from the point of view of a critical examination of solidarity.

are we, when faced with a global pandemic? Showing the limits of an approach of standardised taxonomy, which would engage with mapping out relationality as a physical interconnectedness, and taking into consideration emotional responsiveness, Hellsten shows the contribution of the ethics of care approach. Through examples of her own personal response as well as the discourse of the Finnish government to the upcoming COVID-19 pandemic in Finland in March 2020, Hellsten shows how an ethics of care approach fuses religious/spiritual traditions and secular knowledge and is able to shift our viewpoint away from theoretical categories that obscure important aspects, such as economism. As a result of this ethics of care approach to the pandemic, it is possible to gain a new perspective on hospitality - developing an attitude which includes the needs that in other frameworks remain largely unseen.

Talvikki Ahonen then brings that issue of humanity's responsibility to act into a concrete situation. Her article deals with how church asylum is used for helping people who fall between the gaps inside the system of international protection. It highlights the precarious position of being a guest, or receiver of hospitality, in a context of highly asymmetrical relations. Ahonen highlights and discusses the specific conditions of agency that come into play when illegal immigrants have been taken under the care of the workers of the religious institution. She also addresses the emotional struggles and gendered images that come up in these situations.

Hospitality is much more than an individual undertaking, as Miranda Imperial shows in her article in which she takes up a case study of a pro-migrant social platform in the secularized society of contemporary Catalonia. Working through the notion of hospitality as developed by Jacques Derrida, Emmanuel Lévinas and Luce Irigaray, Imperial explores to what extent collective action contributes to hospitality. Here hospitality becomes an allocation of freedom and an endorsement of sharing amidst differences - going beyond traditional understanding of hospitality and allowing for a non-hierarchical understanding of hospitality.

The issue ends with two reflections from participants in the symposium, Sagy Watemberg Izraeli and Israel Barroso, and two book reviews. 
The question of what hospitality is, and how it can and should be practised, remains an open question. For to give a definite answer would mean that future voices are excluded, and that one perspective can entail all others. This need for openness and the call for engagement lies at the heart of what hospitality is. This is needed in the world, to come to terms with some of the problems which have been addressed in this issue - from climate change to migration. But it is also what is needed in academia - to be the laboratory, to use the word used by Israel Barroso (this issue) in his description of the NSU symposium, in which there are dialogues between theory and praxis, between religion and secularism, between feminism and religiosity. And this is what the NSU study circle will continue to strive for. And this special issue at Approaching Religion will hopefully contribute to that and share this approach with a broader audience.

\section{Laura Hellsten and Nicole des Bouvrie Guest Editors}

\begin{abstract}
Laura Hellsten is a postdoctoral fellow in the Stiftelsen Åbo Akademi Centre of Excellency BACE. There she works as an ethicist ethnographically participating in a transdisciplinary research group studying the functions of cells. She currently also leads the project 'Forcing

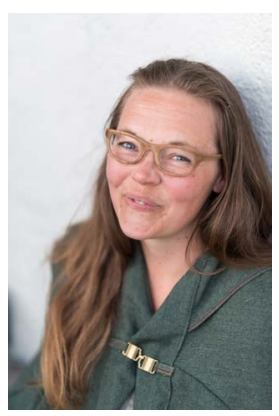
the Impossible - Avtryck i det Okända', that brings together artists and researchers around the theme of science communication. She has written articles around current and historical practices of dance in Western Christian Theological traditions. Her doctoral thesis Through the Bone and Marrow: Re-examining Theological Encounters with Dance in Medieval Europe, will be published by Brepols in 2021. Together with Nicole, Laura leads the study circle on femi-
\end{abstract}

nist philosophy at the Nordic Summer University and functions currently as the study circle coordinator in the board of NSU. She furthermore always refers to her cat Moses as being one of the most important teachers of philosophy in her current life situation.

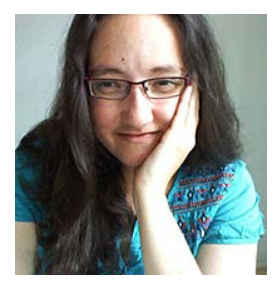

Nicole des Bouvrie is a freelance philosopher and author. She obtained her $\mathrm{PhD}$ at the European Graduate School (2014). Her doctoral thesis, supervised by Anne Dufourmantelle, was published

under the title Necessity of the Impossible (Exilic Press, 2019). In the monograph Diagnosis of the Contemporary Philosopher: Why Philosophers are Mad (in Dutch, Damon, 2018) she explores the consequences of philosophy when understanding that as an embodied practice of living, basing her diagnosis on the psychiatric definitions that can be found in the DSM. She teaches at an art school in the Netherlands and has a private practice as a therapist. As a coordinator of the study circle on feminist philosophy at the Nordic Summer University, but also in her other endeavours, Nicole strives to develop spaces of thought where encounters between people can lead to something more. She enjoys writing (speculative) fiction as a way to present an embodied presence of philosophical thought. 